\title{
Religion and the Study of Social Memory
}

\author{
TUULA SAKARANAHO \\ University of Helsinki
}

\begin{abstract}
In recent decades memory studies have gained great popularity in the humanities and social sciences, and not without cause. At least since the 1980s we have witnessed something which has been called an international memory boom. The article first looks at some explanations as to why memory fascinates people of our own time; it then focuses on questions as to how we can study religion from the point of view of social memory. The discussion is based on ideas derived from the French sociologists Maurice Halbwachs and Danièle Hervieu-Léger, and is structured in terms of recollection, events, narratives, communities and tradition. Finally, I reflect upon the criticism directed against the theory of religion as a chain of memory in the study of world religions, the latter of course being one of the main tasks of our discipline. In the concluding remarks, I comment on the simultaneous rise during recent decades of religion and of a worldwide interest in memory: both address the need to belong to and be part of something larger.
\end{abstract}

Keywords: religion, social memory, recollection, events, narratives, communities, tradition

Memory studies have in recent decades gained great popularity in humanities and social sciences, not without cause. At least since the 1980s we have been witnessing something which has been called the 'commemorative fever' (Misztal 2003, 2), the 'obsession with memory' (Huyssen 1995, 3), or the 'passion for memory' (Nora 1996). Along with this memory boom (Blight 2009), in humanities and social sciences there has developed 'a well established and burgeoning interest in the social nature of memory' (Middleton \& Edwards 1997, 2; see also Radstone 2000).

The above-mentioned 'memory boom' raises several questions: As a social phenomenon, how does this wide interest in memory manifest itself, and what are the reasons for this popular orientation towards the past? And, from the point of view of our discipline, what can we learn from research on memory as a social phenomenon, and how have memory 
studies been utilised in the study of religions? In the following, I first look at explanations as to why memory fascinates people of our own time, and then focus on questions as to how we can study religion from the point of view of social memory. The discussion is based on ideas derived from the French sociologists Maurice Halbwachs and Danièle Hervieu-Léger, and is structured around the terms of recollection, events, narratives, communities and tradition. Finally, I reflect on the criticism directed against application of the theory of religion as a chain of memory to the study of world religions, the latter of course being one of the main tasks of our discipline. In the concluding remarks, I note the simultaneous rise during recent decades of worldwide interest in memory and in religion: both address the need to belong and to be part of something.

\section{Social Memory: Phenomenon and Causes}

According to Barbara Misztal $(2003,2)$, the 'astonishing burst of interest in social memory' manifests itself in the popularity of civic anniversaries of national and international wars, the growing interest in the memories of ethnic groups, the revival of heated debates over the Holocaust and the Vichy regime, and, at the end of the Cold War, the release of previously suppressed memories. In addition to the citizens of newly democratised countries in Eastern Europe, people in South America and South Africa are reassessing their national pasts and publicly debating about the sufferings and wrongs that have occurred in their societies. In the age of globalisation, furthermore, the national identity is increasingly debated not in terms of state and nation but rather with reference to cultural and collective memory. Moreover, the process of migration and the consequent relocation of people have given importance to questions of cultural memory in relation to minority rights and national inheritance. In these debates, says Misztal, the past is used as a screen onto which different groups can project their contradictory views in objective form (Misztal 2003, 1-2).

In addition to political issues, the memory boom is also apparent in the popularity of the different sites of remembrance which have gained popularity as important objects of tourism and heritage movements, and of museums which contain artefacts belonging to a national inheritance or to the history of a particular people, such as the Jewish Museum in Berlin or the National Museum of the American Indian (Smithsonian Institute) in Washington D.C. The film industry too is very keen on utilising historical themes, and the way in which it reconstitutes the past effectively fashions the 
public image of some key moments in our history and their remembrance. (See Huyssen 1995, 1-9; Misztal 2003, 2.)

Consequently, the past has become a heavily contested territory. What makes this contestation so important is that it concerns not only the past of individuals and groups but also their present life and identity. In one way or another, recovered memories must be reconciled with the present (see Pine 2011, 2). Images of the past are also often used to legitimate a present social order (Connerton 1989, 3); it is therefore important to pay attention to what memories are chosen for remembrance and how this is selection takes place. As noted by Emilie Pine: 'To remember is not a straightforward injunction: culture frames the past in political ways' $(2011,3)$.

According to Pine, the answer to the question as to why, over recent decades, the past has become so attractive is twofold. First, it has something to do with the constant and rapid changes that are characteristic of our time. As an example she mentions technology, which introduces new things so rapidly that it is practically impossible to keep pace with the process. When everything is in constant flux, 'cultural remembrance of a supposedly more stable past works to provide a reassuring anchor, a line of progression, and a balancing sense of continuity and groundedness' (Pine 2011, 5; see also Huyssen 1995, 7). In other words, returning to the past can foster a sense of security in a world of insecurities.

Second, during recent decades there has been a crucial change in the ways the past is reconstructed and by whom. Producing different versions of the past is no longer the sole prerogative of professional historians, who have access to archives and the authority to write 'History'. Rather, producing narratives of the past has become a 'mass activity', one which thrives on personal memories with subjective meanings. As against impersonal history, in memory the past is an attractive focal point in a very individual and intimate way. (Pine 2011, 6; see also Fentress \& Wickham 1992, 5-8; Wertsch 2009, 124-7.) Writing one's memoirs has become a popular pastime for ordinary people, and autobiography is no longer the exclusive privilege of those in prominent social positions. The activities of writing one's memoirs or tracing back one's family tree are of course greatly enhanced by the electronic media and especially by the Internet, which make te archival material much more accessible now than before (Misztal 2003, 2). Thus it would seem that the political democratisation of previously oppressed societies, but also the democratisation of access to knowledge and to the field of publishing, have greatly enhanced the visibility of social memory and strengthened its popularity. 
The field of memory studies assuming a social and cultural perspective is still as a whole highly incoherent and dispersed (see Erll 2010); similarly, as of yet there has been no readily available systematic or comprehensive overview of studies dealing with religion and social memory. Given the extent and diversity of research in this field, the task would be very demanding if not impossible. In a brief article such as this, the discussion of religion and social memory is bound to be even more limited and selective. There are a myriad of issues which are crucial for our understanding of 'how religions remember': how religious communities are constructed through remembrance, and how they act in the process of remembering.

\section{Religion and Memory: General Viewpoints}

Along with the humanities and the social sciences, the social nature of memory is also topical in research on religion. As an example I might first mention the German Egyptologist Jan Assmann, whose studies on religion and cultural memory extend from ancient Egypt to contemporary Europe (2006; see also Assmann 2010; see Jackson and Redin in this issue). Indeed, it is this vast time span that makes Assmann's work so valuable for the study of social memory; examples drawn from Ancient Assyria, Egypt and Israel effectively bring home the fact that the preservation and reconstruction of communal memory is not only a contemporary phenomenon but has played an important part throughout history (see Cubitt 2007). The ideas of cultural memory have been further developed by Aleida Assmann, who has reflected, among other things, on the dynamics of cultural memory between remembering and forgetting (2010). Religious memory has also been theorised in the sociology of religion by the French sociologist Danièle Hervieu-Léger (2000), whose insights into religion as a chain of memory have informed for instance the study of Grace Davie (2000) on social changes in Europe. The connection between religion and memory has also been studied in historical contexts in relation to Mesopotamia (Jonker 1995), the Middle East (Lassner 2000), medieval Spain (Beckwith 2000), and early Christianity (Castelli 2004; Kirk \& Thatcher 2005; Kelber \& Byrskog 2009; see Uro in this issue), to mention but a few. In addition to contemporary Christianity (see Hervieu-Léger 2000; Davie 2000), for instance, Islam (Sakaranaho 2003; Waugh 2005; Luz 2008), Judaism (Yerushalmi 1996) and Hinduism (Geaves 2009) feature in recent studies on religion and memory. This list could be further extended, but those mentioned should suffice to demonstrate that the concept of memory has gradually established its place in the study of religions. 
The studies mentioned here make use of the concept of memory from a variety of viewpoints. What unites these different studies is the realisation that there is no religion devoid of social or cultural memory. ${ }^{1}$ Although it is an individual who remembers, memory is always and unavoidably collective by its very nature. As individuals, the faculty of memory and the consequent process of remembering are fundamental to our ability to conceive the world and to constitute our identity. Furthermore, the process of remembering is not only a personal act but always takes place within a certain social context and is socially mediated. In other words, memory is intersubjectively constituted, and it is therefore important to take into account the social dimension of human memory. (Misztal 2003, 1-6; see also Fentress \& Wickham 1992; Wertsch 2009.) 'In reality, we are never alone', says Halbwachs $(1980,23)$.

The French sociologist Maurice Halbwachs, inspired by Émile Durkheim, argued already some eighty years ago that memory is a social phenomenon and that 'it grows into us from outside' (Assmann J. 2006, 1). He introduced the concept of collective memory (Halbwachs 1980; 1992), arguing that 'through their membership of a social group - particularly kinship, religious and class affiliation - [...] individuals are able to acquire, to localise and to recall their memories' (Connerton 1989, 36). ${ }^{2}$ Here I take Halbwachs' ideas of collective memory loosely as a starting point for discussing issues relating to religion and social memory. Particularly useful for this purpose is his study The Legendary Topography of the Gospels in the Holy Land (Halbwachs 1992; see also Castelli 2004).

\section{Recollection}

In his study entitled Legendary Topography of the Gospels in the Holy Land, Maurice Halbwachs (1992) looks at the Gospels as a collection of memories held in common by a group, and hence as the outcome of a collective and partly popular process of elaboration. To put it concisely: Halbwachs describes a process whereby certain events, taking place at a particular time and place, are remembered in testimonies and are thereby reconstructed into the form of a narrative, shared by a group. These narratives in turn

1 For the sake of simplicity, I use throughout this article the term 'social memory' (see Connerton 1989; Fentress \& Wickham 1992) as an overall term including 'cultural memory' (see Assmann J. 2006) or 'collective memory' (see Wertsch 2009).

2 For critical discussion of Halbwachs' ideas see Douglas 1980; Connerton 1989; Coser 1992; Misztal 2003. 
affect the way that for instance visitors to Jerusalem recreate in their imagination holy places which were actually situated in a different location in the city. (Halbwachs 1992, 193-5.) It is thus perhaps not too farfetched to see the process of recollection as a hermeneutic circle of memory, in which certain key events of a religious tradition are constantly reinterpreted and refashioned following a lineage of religious actors functioning as past and present 'witnesses' (see also Hervieu-Léger 2000, 88).

The above-mentioned process of recollection, however, does not only take place within a religious tradition but is also inter-religious. According to Halbwachs, every religion evolves out of religious traditions preceding them; thus there is no absolute beginning in any religious tradition (cf. Halbwachs 1992, 86). Even so-called founded religions, such as Christianity and Islam, always evolve out of pre-existing religious traditions. One can therefore agree with Paul Connerton $(1989,6)$ : since the absolutely new is inconceivable, all beginnings contain an element of recollection. Even when people try to mark out the boundaries of a radical beginning, 'the attempt to establish a beginning refers back inexorably to a pattern of social memory' (Connerton 1989, 13). Thus every religion is, in one way or another, a 'reproduction' of prevailing traditions. In 'thinking globally about religions', Mark Juergensmeyer notes: 'Though most religious traditions claim some ultimate anchors of truth that are unchangeable, it is indisputable that every tradition contains within it an enormous diversity of characteristics and myriad cultural elements gleaned from its neighbours' $(2006,5)$.

Generally this sort of fusion of different religious characteristics is taken at a face value in connection with the Asian religions of India, or China and Japan in particular. Interestingly enough, Andrew Walls $(1997,59)$ argues that in some ways Christianity has been 'the most syncretistic of the great faiths, while never losing the marks of its Jewish origins'. This infusion of traditions is usually referred to as 'syncretism', more often than not in a highly pejorative sense. From perspective of the study of religions, however, syncretism is characteristic of all religious traditions, which can therefore be perceived in the light of post-modern terminology as 'hybrids' of different making.

Admittedly, this is not necessarily the view of those religious adherents, especially within theistic religions, who see their religious tradition as pure, unique and uncontaminated by other traditions. And to some extent they are justified: in order to be viable, a religious tradition has to develop something which is distinctively its own and which thereby sets it apart from the rest. 
One way to do so is to fix certain events as immovable points of reference, which are then regularly commemorated both verbally and ritually.

\section{Events}

One can hence argue that, at the most concrete level, all religious traditions assign importance to certain events, which are embodied in people's beliefs and actions. These events can be historical, as in the so called 'historic religions', such as Christianity, Islam and Buddhism, or they may be mythical, as in some of the 'primal religions'. In all world religions, however, the line between the historical and the mythical is rather shadowy. Events concerning for instance the founders of the 'historic religions' are told differently in religious and non-religious accounts. Religions produce hagiographies of their founders, such as Siddhartha Gautama or the Prophet Muhammad, which are constituted of mythical elements attached to their lives (Pyysiäinen 1988; Gabriel 2007; see also Reynolds \& Capps 1976). For the scholar of religions, the question whether certain core events of a religious tradition are historical or mythical is not necessarily all that important. What is important is the world of meanings that these events convey to those who witness these events, or who hear or read about them, and the actions that follow.

Events generally relate to particular figures who are important for a given religion. In the so called 'founded religions' we find charismatic figures, such as Jesus, Muhammad, or Siddhartha Gautama, who were followed by disciples; the latter acted as eye-witnesses to the actions of this central figure (see Carrithers et al. 1986). In their testimonies these followers recount the words and deeds of the founder, thereby transforming his life and work into a narrative. With respect to different episodes in the life of the founder, these narratives invoke a form of behaviour which is then seen as characteristic of that particular religion. These narratives of exemplary figures are also normative for adherents to a religion.

Christianity, Islam and Buddhism give great importance to the time when the founding figure of these religions was active. This seminal phase of the religion, however, is very brief, coinciding more or less with the lifetime of the founder. The founder's death gives rise to a process of remembrance, and from there on these religions have been constituted in a constant process of commemoration. (See Halbwachs 1992, 94.) Halbwachs makes an interesting observation concerning the founders of religions: he points out that there is no religion (that we know of) with more than one founder. In Christianity, for instance, it is Jesus who is the Lord, the Son of God and the Saviour (see 
Byrskog 2009, 13-14). In Islam, Muhammad was the successor of a long line of prophets but he was the last, the Seal of Prophets, and the Prophet who is mentioned in shahada. In general, it is of course an interesting question as to why this should be so; why a religion cannot have multiple founders, operating simultaneously. Halbwachs' answer to this question is that having multiple founders would be detrimental because it would cast doubt upon the Divine revelation and diminish each individual founder, leaving confusion as to their superiority over the other. It is the single founder - and he alone - who stands apart from all others, as the source of religious and moral renewal. (Halbwachs 1992, 112.)

From a rhetorical point of view, this observation by Halbwachs concerning a single founder is important, when read against Kenneth Burke (1950), who noted that in complete unity there is no rhetoric. What this single founder signifies is a state of total unity, and thus a state of no rhetoric. If there were multiple founders there would be contestation and disunity, ensuing in argumentation. For religions such as Christianity and Islam, a belief in the core of the religion, devoid of any disunity and argumentation, is important. In one way or another the integrity of these traditions depends on this core, purified of contestation (see Shils 1981, 97-8). This belief in the contest-free core of a religious tradition is of course in complete contrast to the way religions are approached in the study of religions, which I discuss further in the following.

\section{Narratives}

It is by the testimonies of eye-witnesses, or 'ear-witnesses', that events are constituted as narratives, and these narratives in turn invoke the events which are at the core of a religion. It must be noted, however, that these narratives can be both verbal and performative. Chris Park $(1994,245)$ refers to an old saying: 'Religion's in the heart, not in the knees'. Paul Connerton (1989), studying habitual patterns of behaviour, would probably argue the opposite: that religion is in the 'knees' rather than the 'heart' (see Shils 1981, 94-100). I suppose we can agree that religion is both in the heart and in the knees; heart and knees simply being different sites of religious observance.

Verbal narratives can be divided into oral and written, which, however, are mutually entangled in each religious tradition in many ways. Elisabeth Tonkin $(1992,3)$ has argued that 'orality is the basic mode of communication'; even in the most literate religions, basic communication from one person to another takes place orally. Moreover, religions often show high 
regard for skills in orality. In religion, things are certainly done by words: sins are forgiven, blessings offered, sanctions laid etc. Thus religions can serve as a vast source of material for someone who wants, following in the footsteps of John Searle (1979), to study religious language as a speech act.

The modes of oral and written communication are of course somewhat different. Written communication represents continuity and security, the will to and the authority of truth, as well as distance between people, whereas oral communication is ever-changing and hence insecure, involving negotiation and proximity between people. (Blomstedt 2003, 121-4; cf. Goody 2000; 2010.) In a similar vein, Connerton distinguishes between incorporating and inscribing practices: the former refers to various bodily activities, the latter to writing devices (as well as modern devices for storing and retrieving information). In his view, the 'transition from an oral culture to a literate culture is a transition from incorporating practices to inscribing practices'. He also maintains that, since accounts become fixed in writing, transmitting the memory of a culture in writing rather than orally narrows down the possibilities for improvisation and innovation. (Connerton 1989, 74-5; cf. Goody 2000, 15.)

With respect to religious traditions, the emblems of this sort of inscription are of course the various canons which aim at fixing and limiting the scope of a tradition as it is remembered and transmitted from one generation to the next. However, as noted by Samuel Byrskog $(2009,7)$ in relation to Judaism, both written and oral traditions are technically handed on by means of memorization; the main difference between them is that a written text must be learned from reading and the latter by repeating what a teacher says. In any case, the line between orality and writing in the development of different religious traditions is not as straightforward as Connerton's assertion would have us believe. Text and utterance as 'means of communication are cumulative rather than replacements' (Goody 2000, 11). Religious meanings, even when inscribed, are never fixed once and for all, but on the contrary are constantly renegotiated. Some sort of contestedness is a basic feature of all living religious traditions, and it is this contestedness which makes them viable (cf. Fernandez 2008, 653). One of the main topics in these contestations is the past of the religious tradition, constantly relived and reinterpreted.

With respect to performative narratives, or 'narratives in action', Paul Connerton (1989) argues that images of the past and recollected knowledge are conveyed and sustained by ritual performances. Moreover, in rituals religious myths retold and re-enacted safeguard a religious tradition against oblivion (Assmann J. 2006). In his How societies remember Connerton aims 
at an account of how practices of a non-inscribed kind are transmitted, in and as a tradition $(1989,4)$. His approach is articulated mainly in relation to politics, but it is also useful for the study of religions. After all, the main events of a religious tradition are not only told or inscribed but also enacted in different rites and rituals. Rites and rituals in turn involve various kinds of bodily practices, which by means of repetition keep up what Connerton $(1989,72-3,88)$ refers to as 'habit-memory'. Helena Kupari's case study of the religious practices of Karelian Orthodox women nicely illustrates how the individual's embodied memory functions as a reminder of her religious tradition and a source of solace in everyday life (see Kupari in this issue).

Habit memory in religious practice can take many forms: from highly formalised ceremonies, such as the investiture of religious personnel, to small individual gestures forming part of a 'lived religion' (McGuire 2003), such as lighting a candle or blessing oneself. Another concrete example of different bodily practices is of course the way people dress. Most religions have instructions about wearing a certain type of garment for ritual purposes but a particular item of dress may also be worn as a marker of identity or even as a political statement, as has happened with women's wearing of the scarf in contemporary Islam.

\section{Communities}

Whatever forms the narratives might take it is important for their development and survival that they manage to persuade a certain audience. After all, individual narratives do not constitute a religion, but narratives told and enacted by a group. Bellah et al. published a book in 1985 called Habits of the Heart, where they discuss communities of memory; they argue that religious communities are examples of what they call 'genuine communities of memory'.

Genuine or not, communities of memory are constituted by their past and are involved in retelling their story, which is their constitutive narrative. As mentioned above, these stories offer examples of men and women who have embodied and exemplified the meaning of the community. Stories of a collective history and of exemplary individuals are an important part of the tradition that is central to a community of memory. From the community's point of view, the stories of exemplary individuals - whether of the founders or others - encapsulate conceptions of character: of what a good person is like, and of virtues that define such character (heroes and heroines). (Bellah et al 1985.) 
Saints no doubt constitute one such group of exemplary individuals. Elizabeth Castelli very vividly describes the Catholic tradition of taking a new name at confirmation as entering into a mysterious realm; the names she and her companions chose established connections between them and various saintly lineages. She further notes that girls were much more prone to 'the drama of the moment'; ' [f] or many of the girls, the search for "my saint" became a search for a secret connection, a hidden narrative, an obscure but therefore especially true story'. In choosing their saint, both girls and boys were taking part 'in a ritualized practice of collective memory'. (Castelli 2004, 2.)

To rephrase this in terms of Kenneth Burke (1950): religious stories offer members of a religious community a rich source of identification, while at the same time they also show what and whom one should dissociate oneself from. These stories are not simply narratives of the past shared by a group; they also have a normative function, giving the group an identity. Thus reference to collective memory justifies certain ways of believing and acting and hence operates as a matrix for living in the present. In addition, however, reference to the past as a justification for the present is often linked to the group's future, since its survival is seen as depending on the continuity of its traditions.

Indeed, communities do look not only backward but also towards the future; hence we might say that religious communities are in most cases 'communities of hope' (Bellah et al. 1985). Yet again, religions also offer eschatological narratives of destruction and the end of the world, but membership in a particular religious group usually brings hope. As noted by Bellah et al. $(1985,153)$ : religions as communities of memory allow us to connect our aspirations for ourselves and those closest to us with those of a larger whole, and to see our own efforts as being, in part, contributions to a common good. As encapsulated by Chris Park: 'religion serves to unite believers and it gives them a meaningful way of interpreting what is going on around them' $(1994,55)$. In sum, we can look at religions as selfinterpreting communities (cf. Connerton 1989, 12), which create their sense of continuity by recounting their founding myths or narratives in relation to both past and future.

\section{Tradition}

The above discussion, inspired by the work of Halbwachs, can be enriched by Hervieu-Léger's (2000) definition of religion as constituted of three 
elements. The first is 'the expression of believing', which can be identified with narratives, whether verbal or performative. The second element in her definition of religion is 'the memory of continuity', which of course is something upheld by a community. Religious communities constitute their past in the form of a chain of memory, in which certain people or events are re-invoked as the main markers of identity. The third element in HervieuLéger's definition is 'the legitimizing reference to an authorized version of such memory, that is to say to a tradition'. (Hervieu-Léger 2000, 97; see also Shils 1981, $12 \mathrm{ff}$.) Hence tradition is constituted as a point of reference used in the legitimation of an identity and of the continuity of a religious community. As an imaginative reference, religious tradition operates ad intra as a source of identification and consensus, and ad extra as a source of dissociation. (Hervieu-Léger 2000, 81-4.) In other words, resorting to a tradition creates boundaries.

What a religious community accepts as tradition comes from the past but carries authority in the present. Here it is less important how far back this past reaches, and whether it is historical or mythical, but rather that it is actively invoked by individuals and/or religious communities. We can thus speak of the Hindu tradition, which has lasted nearly five thousand years, or of the new pagan tradition, which is only some fifty years old but which in its own rhetoric aims at invoking the pre-Christian traditions of Europe. As such, such invocation of the past can be fairly simple, as in 'it's always been done this way', or highly formalised, as in the case of doctrinal traditions. Whatever the case may be, in the process of invocation the tradition is established as a norm for individuals and groups. (Hervieu-Léger 2000, 87.)

With respect to the continuity of a religion, a tradition constituted by invoking the past can operate as a source not only for the preservation of the status quo but also for the innovations and reinterpretations demanded by the present (Hervieu-Léger 2000, 87). Since the social mechanisms for regulating reference to tradition are part and parcel of the dynamic of social relations whereby a religious community creates itself and its own history, tradition is not simply a repetition of the past in the present. Rather, the distinctive mark of tradition is that it actualizes the past in the present, thereby restoring to human lives its essential core. Thus tradition cannot be reduced to established fundamental references, such as sacred texts or immovable rituals, set for all time. Tradition evolves in a hermeneutic process, one in which a religious community re-reads its ritual and statutory practices, its own historical narrative and institutions. (Hervieu-Léger 2000, 88.) 


\section{Social Memory and the Study of World Religions}

In referring to religion, both Halbwachs and Hervieu-Léger mainly focus on Judaism and Christianity. From the perspective of the study of religions, this limited focus inevitably raises the question as to what extent the theoretical insights of these sociologists can be applied to world religions in general. This is precisely the criticism posed by Ron Geaves, who refers to the case of Prem Rawat in challenging Hervieu-Léger's theory of religion as a chain of memory, or 'authority invoked in support of an act of believing' (Geaves $2009,19)$. It is not possible here to go into detail with regard to Geaves' nuanced theoretical discussion; in the following, I merely briefly summarise his general line of argument for the purposes of the present discussion.

Prem Rawat is a teacher of Indian origin, who arrived in the West in beginning of the 1970s and who is generally perhaps best known for his influence on organisations, such as the Divine Light Mission, which throve during the seventies especially in the United States. Prem Rawat himself, however, has worked actively all his life to deconstruct any institutional forms of religiosity that have developed around his teachings, and he has also made an effort to sever any ties that his teaching might have with his spiritual roots in North India. (Geaves 2009.)

Since Prem Rawat does not acknowledge his teaching as part of any tradition and hence conforming to the teachings of any particular predecessor, Geaves sees him as an iconoclast, who 'breaks the bounds of tradition while maintaining an emphasis on the inner experiential dimension', but who, specifically for this reason, can be identified with the Indian Sant tradition as 'a holy man of a rather special type, who cannot be accommodated in the traditional categories of Indian holy men'. ${ }^{3}$ Prem Rawat himself does not accept this categorization; but, as Geaves insists, even solitary Sants cannot avoid some sort of institutionalisation and development of traditions that would fit in with Hervieu-Léger's definition of religion as a chain of transmitted tradition $(2009,24)$. This identification, however, creates a paradox: the solitary Sant is part of the Indian religious tradition, but Prem Rawat, who is in opposition to any set tradition, is in a sense attempting to create a 'traditionless tradition'. What the case of Prem Rawat shows is that it is very hard to do so; it takes effort to work constantly against the grain, and

3 Geaves (2009) explains Rawat's continuous effort to deconstruct any set patterns of behavior and belief by combining viewpoints from the post-Weberian sociology (Thomas O'Dea) and research on Indian religion focusing in particular on the Sant tradition (Charlotte Vaudeville, Daniel Gold). 
can ultimately lead to psychological and spiritual exhaustion (see Geaves 2009, 29).

It is hard to say yet what the future of Prem Rawat's teaching will be after his death. He is surrounded by a group of founder-leaders who have been his faithful followers for thirty years, but is there anyone among them possessing enough charisma to take his place? Or has Prem Rawat's process of deconstruction been brought to fruition, so that none of these ever-faithful followers will transmit his teachings further? It is hard to believe that people who have given their lives to supporting and following Prem Rawat's teaching would simply cease to do so at his death, but only the future can tell.

In any case, as noted, Geaves uses the case of Prem Rawat to question the universality of Hervieu-Léger's theory of religion. The larger theoretical framework of Geaves' article is 'the debate in the study of religion between those who maintain that religion exists as a sui generis category and those who argue that religion is merely a sub-set of cultural phenomena' $(2009,19)$. Geaves takes up Hervieu-Leger's theory of religion as a chain of memory as the test case of a reductionist approach which claims to provide a 'universal methodology' (Geaves 2009, 20; italics original), and which hence should also be applicable to religions other than Christianity, such as Indian religions. One can fully agree with him that a universal theory should work for all religions, not only for Christianity. However, his criticism of HervieuLéger's theory can be met with certain counter-arguments, which place his criticism in a new light.

Briefly, Geaves gives at least two reasons why Hervieu-Léger's theory of religion does not meet his basic requirement for the study of religions (in the plural). First, she overlooks the experiential dimension, which is crucial for instance in the formation of Indian traditions; instead she places too much emphasis on doctrine, which was important in the development of Christianity. Second, according to Geaves, the impact of a Judaic and Christian narrative is also evident in the fact that in her theory linear time is essential to chains of memory, whereas the chain of memory maintained by both Vedic and non-Vedic religions is best understood as cyclic. (Geaves 2009, 30-1.) These observations concerning the formation or development of different religious traditions in their respective narratives are very important indeed, and are useful to keep in mind in studying religions from the point of view of memory. However, in my view, the suitability of Hervieu-Léger's theory of religion in the study of world religions can also be defended on the grounds of her overall line of thought. 
Hervieu-Léger studies 'modern religion' and 'religious modernity', as she calls it, and in so doing proposes a definition of religion which is strictly related to the 'sociological viewpoint required for the purpose of analysis', because, as she emphasises, ' $[t]$ he sociologist is not concerned to know once and for all what religion is in itself, but to comprehend changes in the sphere of religion, considered by way of its tangible socio-historical manifestations' $(2000,69)$. Thus a definition of religion is for her, as for some other sociologists of religions, 'a working tool', which helps her to comprehend the modern transformations of religion (Hervieu-Léger 2000, 69, 81-2; see Casanova 1994, 218; see also Sakaranaho 2006, 25-7).

Although Hervieu-Léger's discussion is mainly limited to Europe, her approach is also applicable to other socio-cultural contexts, for the very reason that her definition of religion is offered as a dynamic concept for the mapping of different lines of transformation whereby religions are reconstructed. In her understanding, religions - whether traditional or modern - are constantly transformed and remodelled. (Hervieu-Léger 2000, 69ff.) Hence her approach is not really linear, nor does it simply focus on doctrine, but is both personal and social in its orientation. This is obvious in the way she defines believing as 'belief in action, as it is experienced' and emphasises the meanings that people, as both individuals and collectives, give to their beliefs (Hervieu-Léger 2000, 72).

As noted by Geaves $(2009,19)$, the core of Hervieu-Léger's $(2000,76)$ definition of religion lies in 'the type of legitimation applied to the act of believing'; hence her assumption that 'there is no religion without the authority of tradition being invoked (whether explicitly, half-explicitly or implicitly) in support of the act of believing'. What one needs to take into account, however, is that this definition did not emerge out of a study of Christianity but of forms of utopia as envisaged and practiced by neo-rural communities; more specifically, of a group of young and educated people who wanted to experiment with alternative living in Southern France. To make a long story short, this group was not originally religious; as time went by, however, they started to search for legitimation for their distinct lifestyle in the margins of and in the opposition to mainstream society. In their search, they ended up with the invocation of past witnesses who gave validity to their experience and offered them a model for refashioning their enterprise according to forerunners - who in this case happened to be Benedictine monks. What Hervieu-Léger emphasises is that it was not important that members of this group chose a religious (Christian) point of reference to legitimise their experience and action, but that it linked the group to an 
authoritative tradition, and in so doing to a lineage which granted them membership in a spiritual community consisting of past, present and future believers. Based on this case study, she came up with the working hypothesis that 'a religion is an ideological, practical and symbolic system through which consciousness, both individual and collective, of belonging to a particular chain of belief is constituted, maintained, developed and controlled'. (Hervieu-Léger 2000, 76-82.)

What the case study on Prem Rawat paradoxically illustrates is the almost inevitable process whereby a religious teacher and his message gradually seem to become attached to certain collective traditions of belief and action, and hence to some extent institutionalized, unless that teacher works against such a development, as Prem Rawat has clearly tried to do. These processes are not necessarily the result of conscious effort, whereas deconstructing these forms is. The case of Prem Rawat also makes us question the feasibility of such deconstruction in India, where people attach great important to age-old traditions and refashion them in their daily worship (see Geaves 2009, 27). Is it not the case, we may ask, that even against his own will Prem Rawat will inevitably be assigned to some niche in the abundantly rich world of Indian traditions, whether that of the solitary Sant or another, and his teaching interpreted in accordance with this categorization? Despite his personal endeavour to deconstruct any lineage between his teaching and the Indian or other religious tradition, I thus do not see the example of Prem Rawat as a strong case against Hervieu-Léger's theory of religion as a chain of memory.

\section{Concluding Remarks}

Memory as a social phenomenon is a vastly popular topic of research in the humanities and social sciences, and has been utilised in many ways in the study of religion as well. At the bottom of our inquiry into religion and social memory lie questions as to 'how religions remember', in other words how religious communities are constructed through remembrance, and how they act in the process of remembering. In this article I have sought to bring into focus certain perspectives on these questions, mainly gleaned from the sociology of religion. The primary source of inspiration has been the work of Maurice Halbwachs, in tandem with the theoretical discussion of Danièle Hervieu-Léger. With respect to the latter, I also discussed the criticism directed against the theory of religion as a chain of memory in studying world religions other than the Judaeo-Christian 
traditions, the latter being most often used as case studies in sociology of religion.

Underlying our inquiry is the realisation that all religious traditions are constituted, one way or another, in a process of recollection, which by its very nature is always selective as to what is remembered and what is forgotten. This process of recollection gives life to certain events; whether understood as historical or as mythical, these in any case constitute the core of a religious tradition. These events are remembered in testimonies, both oral and written, and hence refashioned as narratives shared by a community. For the community, these narratives function as a normative source of identification, fostering a sense of continuity between past, present and future. In addition to being (re)told, these narratives are also (re)enacted and sustained in action; a good example are rituals, serving as the vehicles of habit-memory. However, the process of recollection is not simple and straightforward but involves constant negotiation. Endowing a particular memory of continuity with authority over others, a community creates a tradition which can operate as a source of consensus. It also creates boundaries between 'us' and 'them'. Hence memory studies can enhance our understanding of the way the past is constituted in different religious traditions as a normative matrix for the present and the future. Moreover, with the awareness of the recollection inherent in any religion, it helps us to avoid approaching religious traditions as separate and self-contained entities, which is how they are portrayed, more often not, in books on world religions.

On a more concrete level, there are several issues concerning religion and social memory which this paper did and could not touch upon. In order to conclude, I will just raise a couple of timely and complex themes which are in need of a further study.

Remembering always goes hand in hand with forgetting. It is obvious that in our own time religious traditions are threatened with massive amnesia, as societies become more and more secular. Grace Davie, in Religion in Modern Europe: A Memory Mutates (2000), discusses from different perspectives the ways in which the chain of religious memory can weaken, become fractured and eventually break altogether. In this age of individualisation, religions no longer carry authority as a unifying matrix for belief and behaviour, as they might once have done. One can therefore understand the efforts for instance of the Christian churches in Europe to preserve their moral vision, in spite of changes in today's world, as a way to manage religious memory in an increasingly diversified world. The 'management of truth' has become a challenge for Christianity, especially in Europe, for the simple reason 
that its authority is no longer taken for granted in a religious field with an ever increasing number of competitors. The main concern of the Christian Churches in contemporary Europe is the gradual extinction of Christian tradition from the collective memory of Europeans. (See Sakaranaho 2006, 27-9.)

However, the fight for survival is also acute, if in a different way, for those religious traditions which aim at rooting themselves in Europe, such as Islam. In the process of migration, one leaves behind a social setting in which a life lived in a certain way is marked by certainties which are to a large extent commonly shared. Living as a newcomer in an unfamiliar society means that almost nothing can be taken for granted; living as a member of a minority encourages or even forces one to actively reflect upon the religious tradition that one was brought up in, but which in the new environment is alien and unknown. Consequently, the reinforcement of an individual chain of religious memory in 'diaspora' requires work and effort, as does the establishment of a new religious community trying to create continuity of the institutional memory of a religious tradition. (Sakaranaho 2006, 29.)

The disruption in one's life caused by migration can be very traumatic if one is forced to leave one's country because of warfare and social unrest. Writing about Somali women in Finland, Marja Tiilikainen (2003; 2005) shows how shrouding traumatic memories in silence can help these women to cope with their present life in Finland but does not protect them from bodily symptoms and feelings of illness. She also reflects on the question of gender: in order to understand women's memories, we need to start with their personal experience but also place them in a larger framework of power relations between women and men (Tiilikainen 2003; 2005). Questions of religion, gender and embodied memory are an important topic of research indeed (see McGuire 2003; see also Narvaez 2006).

It is obvious from the above-mentioned examples concerning secularization and migration that neither remembering nor forgetting are in any way simple or straightforward processes. Depending on the context, there can be many ways and many reasons to either remember or forget. In some cases, what an individual or society chooses to remember or forget is unavoidably a moral choice; the past can cast a long shadow upon a society, and remembering or forgetting its history inevitably becomes a political matter (Assmann A. 2006; see also Pine 2011). Writing about the Holocaust, Avishai Margalit reflects on the ethics of memory and on 'our' obligation to remember people and events of the past. He asks, furthermore: who is this collective 'we' who has the obligation not to forget? (Margalit 2002.) 
This last question is also important in the sense that choosing to remember can have an impact on people's collective identity. As an example one can mention Europe. After the recognition of a collective guilt for the destruction of Jews during the Second World War, Europeans' perception of the religious roots of Europe changed: the cultural character of Europe was no longer seen simply as Christian but rather as Judeo-Christian (Huber 2008). At the opposite extreme, says Paul Connerton, forgetting can also act as an important vehicle in the constitution of a new identity; it opens up a space for present projects $(2008,62-3)$. To some extent this is what happens in the process of religious conversion, where the individual turns to new sources of belief and authority (see Sakaranaho 2003).

Finally, as a scholar of religion, one cannot but notice the simultaneous rise of worldwide interest in memory and religion during recent decades. In a world where everything is in a constant flux, resorting to the past, as noted by Pine $(2011,5)$, can offer some sort of anchor, a sense of continuity and a vision of groundedness. Traditionally religious traditions have answered these needs and to some extent continue to do so, even if in new ways and forms. Remembering, on the other hand, is the process whereby the anchor is cast, the sense of continuity created and the vision of groundedness built. Thus both religion and memory address the need to belong and be part of something larger; which may help to explain the popularity they enjoy in our own time.

Bibliography

Assmann, Aleida

2006 Der Lange Schatten der Vergangenheit: Erinnerungskultur und Gesichtspolitik. München: C. H. Beck.

2010 Canon and Archive. - Astrid Erll \& Ansgar Nünning (eds), A Companion to cultural memory studies, 97-107. Berlin and New York: De Gruyter.

\section{Assmann, Jan}

2006 Religion and Cultural Memory. Stanford: Stanford University Press.

2010 Communicative and cultural memory. - Astrid Erll \& Ansgar Nünning (eds), A Companion to cultural memory studies, 109-18. Berlin and New York: De Gruyter. 
Beckwith, Stacy N. (ed.)

2000 Charting Memory: Recalling Medieval Spain. New York and London: Garland Publishing.

Bellah, Robert N. et al.

1985 Habits of the heart: individualism and commitment in American Life. Berkeley (Calif.): University of California Press.

Blight, David W.

2009 The Memory Boom: Why and Why Now? - Pascal Boyer \& James V. Wertsch (eds), Memory in Mind and Culture, 238-51. Cambridge: Cambridge University Press.

Blomstedt, Jan

2003 Retoriikkaa epäilijöille [Rhetoric for doubters]. Helsinki: Loki-kirjat.

Burke, Kenneth

1950 A Rhetoric of Motives. New York: Prentice-Hall.

\section{Byrskog, Samuel}

2009 Introduction. - Werner H. Kelber \& Samuel Byrskog (eds), Jesus in Memory. Tradition in Oral and Scribal Perspectives, 1-20. Waco: Baylor University Press.

Carrithers, Michael \& Raymond Dawson \& Humphrey Carpenter \& Michael Cook

1986 Founders of Faith. Oxford: Oxford University Press.

Casanova, José

1994 Public Religion in the Modern World. Chicago: University of Chicago Press.

\section{Castelli, Elisabeth A.}

2004 Martyrdom and Memory. Early Christian Culture Making. New York: Columbia University Press.

\section{Connerton, Paul}

1989 How Societies Remember. Cambridge: Cambridge University Press.

2008 Seven Types of Forgetting. - Memory Studies 1 (1), 59-71.

Coser, Lewis A.

1992 Introduction: Maurice Halbwachs 1877-1945. - Maurice Halbwachs, On Collective Memory, 1-34. (Ed., transl. and with an Introduction by Lewis A. Coser.) Chicago and London: The University of Chicago Press.

Cubitt, Geoffrey

2007 History and memory. Manchester and New York: Manchester University Press. 


\section{Davie, Grace}

2000 Religion in Modern Europe. A Memory Mutates. Oxford: Oxford University Press.

\section{Douglas, Mary}

1980 Introduction: Maurice Halbwachs (1877-1945). - Maurice Halbwachs, The Collective Memory, 1-21. (Transl. from Mémoire Collective by Francis J. Ditter, Jr., and Vida Yazdi Ditter.) New York: Harper \& Row.

\section{Erll, Astrid}

2010 Cultural Memory Studies: An Introduction. - Astrid Erll \& Ansgar Nünning (eds), A Companion to Cultural Memory Studies, 1-15. Berlin and New York: De Gruyter.

\section{Fentress, James \& Chris Wickham}

1992 Social Memory. Oxford: Blackwell.

Fernandez, James W.

2008 Rhetorics. - Jens Kreinath \& Jan Snoek \& Michael Strausberg (eds), Theorizing Rituals. Classical Topics, Theoretical Approaches, Analytical Concepts, 645-56. Leiden and Boston: Brill.

\section{Gabriel, Richard A.}

2007 Muhammad. Islam's First Great General. Norman: University of Oklahoma Press.

\section{Geaves, Ron}

2009 Forget Transmitted Memory: The De-traditionalised 'Religion' of Prem Rawat. - Journal of Contemporary Religion 24 (1), 19-33.

Goody, Jack

2000 The Power of the Written Tradition. Washington and London: Smithsonian Institution Press.

2010 Myth, Ritual and the Oral. Cambridge: Cambridge University Press.

\section{Halbwachs, Maurice}

1980 The Collective Memory. (Orig. transl. from Mémoire Collective by Francis J. Ditter, Jr., and Vida Yazdi Ditter.) New York: Harper \& Row.

1992 On Collective Memory. (Ed. and transl. from Les Cadres sociaux de la mémoire (1952) and from La topographie légendaire des évangiles en terre sainte: Etude de mémoire collective (1941), and with an Introduction by Lewis A. Coser.) Chicago and London: The University of Chicago Press.

\section{Hervieu-Léger, Danièle}

2000 Religion as a Chain of Memory. (Transl. from La religion pour mémoire by Simon Lee.) New Brunswick, New Jersey: Rutgers University Press. 


\section{Huber, Wolfgang}

2008 The Judeo-Christian Tradition. - Hans Joas \& Klaus Wiegandt (eds), The Cultural Values of Europe, 43-58. Liverpool: Liverpool University Press.

\section{Huyssen, Andrea}

1995 Twilight Memories. Making Time in a Culture of Amnesia. New York and London: Routledge.

\section{Jonker, Gerdien}

1995 The Topography of Remembrance. The Dead, Tradition \& Collective Memory in Mesopotamia. Leiden, New York and Köln: Brill.

Juergensmeyer, Mark

2006 Thinking Globally About Religion. - Mark Juergensmeyer (ed.), Oxford Handbook of Global Religions, 3-12. Oxford: Oxford University Press.

Kelber, Werner \& Samuel Byrskog (eds)

2009 Jesus in Memory. Tradition in Oral and Scribal Perspectives. Waco: Baylor University Press.

Kirk, Alan \& Tom Thatcher (eds)

2005 Memory, Tradition, and Text. Uses of the Past in Early Christianity. Atlanta: Society of Biblical Literature.

\section{Lassner, Jacob}

2000 The Middle East Remembered. Forged Identities, Competing Narratives, Contested Spaces. Ann Arbor: The University of Michigan Press.

\section{Luz, Nimrod}

2008 The Politics of Sacred Places: Palestinian Identity, Collective Memory, and Resistance in the Hassan Bek Mosque Conflict. - Environment and Planning D: Society and Space 26, 1036-52.

\section{Margalit, Avishai}

2002 The Ethics of Memory. London: Harvard University Press.

\section{McGuire, Meredith}

2003 Why Bodies Matter: A Sociological Reflection on Spirituality and Materiality. - Spiritus 3, 1-18.

\section{Middleton, David \& Derek Edwards (eds)}

1997 Collective Remembering. London, Thousand Oaks, New Delhi: Sage Publications.

\section{Misztal, Barbara A.}

2003 Theories of Social Remembering. Maidenhead, Philadelphia: Open University Press. 
Narvaez, Rafael F.

2006 Embodiment, Collective Memory and Time. - Body E Sociology 12 (3), 51-73.

Nora, Pierre

1996 Realms of Memory. Vols 1-3. (Trans. Arthur Goldhummer.) New York: Columbia University Press.

Park, Chris

1994 Sacred Worlds: An Introduction to Geography and Religion. London: Routledge.

Pine, Emilie

2011 The Politics of Memory. Performing Remembrance in Contemporary Irish Culture. Basingstoke and New York: Palgrave Macmillan.

\section{Pyysiäinen, Ilkka}

1988 Perimmäiset kuvat. Buddhan elämäkerran merkitys theravadan kaanonissa. [Ultimate images. The Meaning of the Buddha's Biography in the Theravada Canon]. Helsinki: The Finnish Society for Missiology and Ecumenics.

\section{Radstone, Susannah}

2000 Working with Memory: An Introduction. - Susannah Radstone (ed.), Memory and Methodology, 1-22. Oxford and New York: Berg.

\section{Reynolds, Frank E. \& Donald Capps}

1976 The Biographical Process: Studies in the History and Psychology of Religion. The Hague: Mouton.

\section{Sakaranaho, Tuula}

2003 Les Rhétoriques de la Continuité: Les Femmes, L'islam et L'héritage Catholique en Irlande. - Social Compass 50 (1), 71-84.

2006 Religious Freedom, Multiculturalism, Islam. Cross-reading Finland and Ireland. Leiden and New York: Brill.

\section{Searle, John R.}

1979 Expression and Meaning: Studies in the Theory of Speech Act. Cambridge: Cambridge University Press.

\section{Shils, Edward}

1981 Tradition. London and Boston: Faber and Faber.

\section{Tiilikainen, Marja}

2003 Arjen islam: Somalinaisten elämää Suomessa [Everyday Islam: The life of Somali Women in Finland]. Tampere: Vastapaino.

2005 Suffering, Social Memory and Embodiment: Experiences of Somali Refugee Women. - Pakistan Journal of Women's Studies: Alam-e-Niswan $12(2), 1-16$. 


\section{Tonkin, Elisabeth}

1992 Narrating our Pasts: The Social Construction of Oral History. Cambridge: Cambridge University Press.

\section{Walls, Andrew}

1997 Christianity. - John R. Hinnells (ed.), A New Handbook of Living Religions, 55-161. London: Penguin Books.

Waugh, Earle $\mathrm{H}$.

2005 Memory, Music and Religion. Morocco's Mystical Chanters. Columbia (SC): University of South Carolina Press.

\section{Wertsch, James}

2009 Collective Memory. - Pascal Boyer \& James V. Wertsch (eds), Memory in Mind and Culture, 117-37. Cambridge: Cambridge University Press.

\section{Yerushalmi, Yosef Hayim}

1996 Zakhor: Jewish History and Jewish Memory. Seattle, WA: University of Washington Press. 